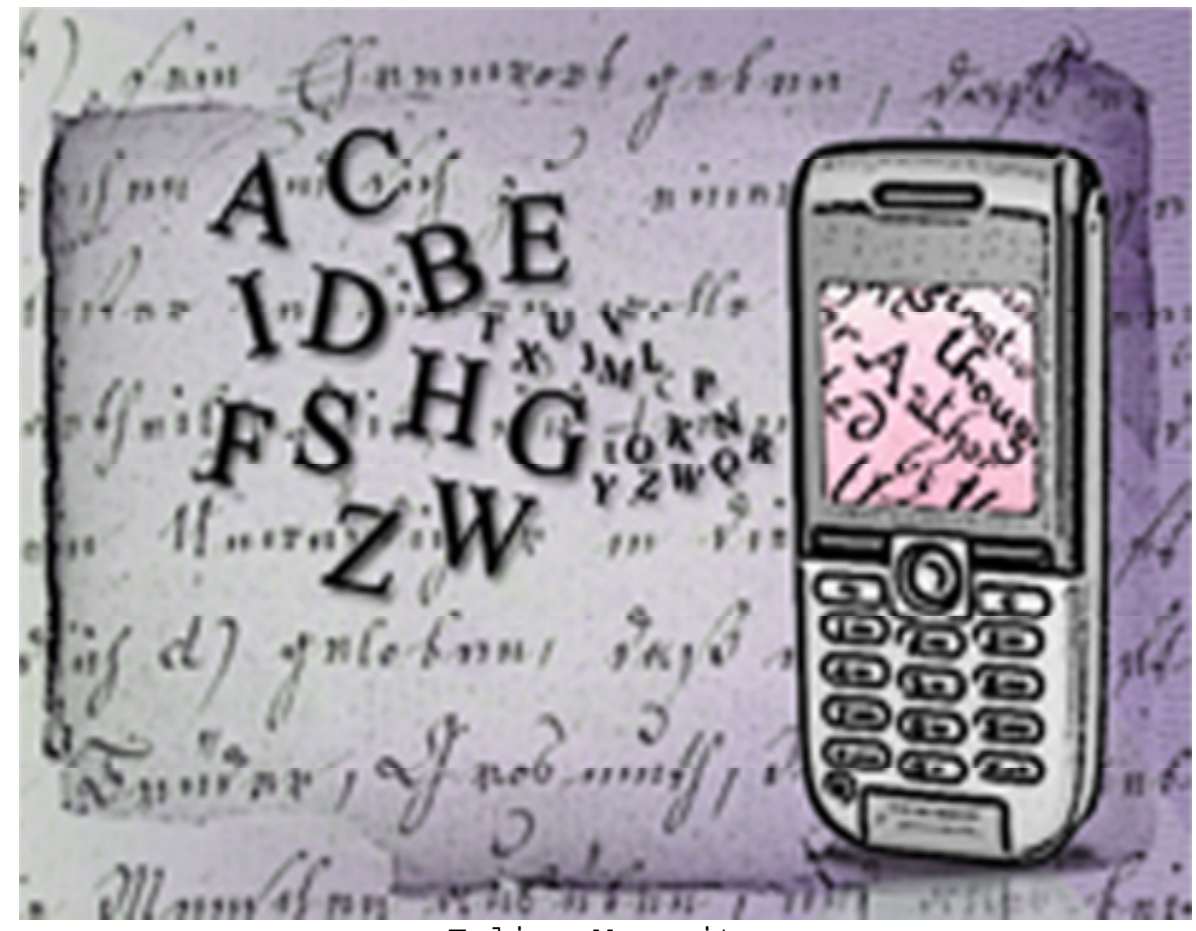

Felipe Mesquita

\title{
CelulArte: possibilidade literária em rede
}

\section{Carlos Alexandre R. de Oliveira}

Graduado em Letras, licenciatura plena em Língua Portuguesa e Língua Inglesa. Aluno do curso de Especialização em Ensino de Leitura e Produção de Textos (FALE/UFMG). Professor de Educação Básica em redes pública e privada do Estado de Minas Gerais.

Como aluno do curso de Especialização em Ensino de Leitura e Produção de Textos (FALE/UFMG), tive acesso às teorias de rede, especialmente à idéia de hipertexto. Enquanto professor de Língua Portuguesa, comecei a trabalhar com essas novas teorias, a partir do suporte do aparelho celular, cujo uso é proibido na Escola Estadual Reny de Souza Lima, em Santa Luzia-MG. Utilizei o celular nas turmas da $3^{a}$ série do Ensino Médio com a finalidade de estimular sua leitura e sua produção de textos literários que, apesar de breves - poemas em tela fossem capazes de provocar a interação dos alunos e fazê-los buscar o prazer da leitura e da interpretação de poesias. 
Essa idéia partiu da leitura e da interpretação de poemas do livro Distraídos venceremos, de Paulo Leminski, as quais foram associadas às comemorações do Centenário da Imigração Japonesa que ocorreram neste ano de 2008 e não estava previsto no plano de curso. Tudo começou com a idéia de trabalhar somente leitura e interpretação, mas os alunos tiveram um enorme interesse pelos poemas "curtos" (nome dado por eles aos poemas), pela obra e pelas propostas da literatura japonesa. Assim, resolvi trabalhar o gênerohaikai, que designa poemas "curtos" e interativos, pois sua simbologia utiliza elementos sutis da natureza, ou seja, qualquer parte da natureza pode tornar-se símbolo e fazer parte da composição de um haikai.

Mas como utilizar o aparelho celular para escrever poesias? Tivemos uma série de dificuldades pois os alunos queriam escrever poemas muito extensos. E uma das características dohaikai é que o mesmo seja escrito em três linhas. Então, deixei-os escrever textos extensos e propus passá-los para a tela do celular, e depois enviá-los a um colega de sala. No decorrer da atividade, os poemas chegavam fragmentados em outros celulares e não dava para visualizá-los de forma coerente porque os versos chegavam em ordem inversa. Portanto, tivemos que adotar as características do haikai e utilizá-las na tela do celular. Isso foi possível porque os aparelhos têm um recurso de recebimento de textos (o Short Message Service SMS), que permite mostrar na tela textos muito curtos, com até 140 caracteres. Resolvida a questão da nova tecnologia de escrita, a produção foi fantástica: os alunos começaram a produzir pequenos textos poéticos e avançaram na invenção de formas e imagens. Sem querer, acabamos entrando no mundo da poesia concreta, o que me levou a pensar no desenvolvimento de um novo projeto de ensino/aprendizagem junto aos educandos.

Como forma de motivá-los a continuar escrevendo os poemas "curtos" e passá-los adiante, com o intuito de formar leitores e produtores de textos em rede, pedi que escrevessem numa lista números aleatórios de celulares sem identificá-los com o nome do proprietário. Depois, puderam escolher qualquer número de celular e enviar um haikai ao mesmo, despertando a curiosidade do receptor da mensagem e motivando-o a responder ou a tentar descobrir quem a escrevera - assim, estávamos trabalhando numa proposta para estimular a inteligência coletiva do grupo. Nesse processo, formamos uma rede literária, por meio da qual estamos atuando até hoje. Bem, vocês devem estar pensando: como eles conseguiram tantos créditos nos celulares para o envio das mensagens, sendo esse um recurso muito caro? Mas nós desenvolvemos a atividade no momento em que as operadoras estavam oferecendo planos de bônus. 
Os alunos descobriram o prazer que a produção literária poderia proporcionar a partir de uma escrita móvel. A relação dos alunos com o celular, a partir dessa interação em rede, deixou de ser apenas uma brincadeira, uma prática utilitátia ou mesmo uma relação de poder (ter o melhor aparelho). Também a desobediência às normas escolares (que proíbem seu uso) foi re-direcionada para outras possibilidades: sua utilização foi permitida e passou a ser uma busca do prazer de ler e escrever textos literários "curtos" e significativos. Essa visão humanizadora do ato de escrever possibilitou diversas transgressões conscientes do ato de registrar sistematicamente o que se pensa. O ato de escrever tornou-se, então, a Arte de Escrever, sem medo, sem pressão, sem modelos autoritários: concretizado com a experiência viva dos próprios educandos, que presentificaram em suas produções os processos lingüisticos, intralingüisticos e extralingüisticos vividos pelo sujeito-autor.

Nesse contexto, a educação não é apenas uma ação técnica que, pela implementação de determinados procedimentos, realiza objetivos preliminarmente estabelecidos. Ela pode transcender - que está instituído, por meio da prática de atitudes transdisciplinares que considerem as várias manifestações de educandos e educadores, diante não só de objetivos cognitivos, mas também de movimentos atitudinais, políticos, filosóficos, vitais e culturais. 